${ }^{9}$ Pauly, M., Hoppe-Seyl. Z. physiol. Chem., 42, 508 (1904).

${ }^{10}$ Gaur, R. D., Goswami, A. K., and Talwar, G. P., Indian J. Med. Res., 60, 932 (1972).

${ }^{11}$ Miyamoto, H., and Chang, M. C., J. Reprod. Fert., 30, 135 (1972).

18 Whitten, W. K., in Schering Symposium on Intrinsic and Extrinsic Factors in Early Mammalian Development (edit. by Raspe, G.) (Advances in Biosciences, 6) (Pergamon/Vieweg, 1970).

18 Whitten, W. K., and Biggers, J. D., J. Reprod. Fert., 17, 399 (1968).

\section{Zirga Virus, a New Arbovirus isolated from Bird-infesting Ticks}

In October 1968, the Department of Entomology at the London School of Hygiene and Tropical Medicine received from the Chief Medical Officer of the British Petroleum Company Ltd, two nymphs of an argasid tick. They were collected from the island of Zirqa (Zarrakkuh) $\left(24^{\circ} 53^{\prime} \mathrm{N}, 53^{\circ} 04^{\prime} \mathrm{E}\right)$ off the coast of Abu Dhabi in the Persian Gulf and were associated with groundnesting ospreys (Pandion $h$. haliaetus) and Socotra cormorants (Phalacrocorax nigrogularis) which appear on the island towards the end of August and remain till early February. The island is barren and uninhabited by humans. Abu Dhabi Marine Areas Limited (ADMA) have a radiomast and generator on the island and ADMA personnel make regular visits for routine maintenance of the plant. Local fishermen also visit the island from time to time. Attention was drawn to the presence of ticks when personnel were bitten by them and reacted with allergic symptoms, septic sores and high temperature. Case history notes are given by Hoogstraal, Oliver and Guirgis ${ }^{1}$. Blood smears from a patient who was ill following tick bites were negative for spirochaetes, protozoa and microfilariae. The ticks were identified by one of us (M. G. R. V.) as Ornithodoros sp. and sent to $\mathrm{Dr} \mathrm{H}$. Hoogstraal of NAMRU-3, Cairo, who assigned them to Ornithodoros (Alectorobius) muesebecki described from specimens collected from a booby colony on Hasikiya Island, South Yemen Republic, in the Arabian Sea ${ }^{2}$.

In November 1969, several specimens of this tick collected from the nests of cormorants on Zirqa Island by the late Dr R. M. Oliver, Senior Medical Officer of the British Petroleum Company, were received. Because it seemed possible that the symptoms in humans following tick bites had a viral aetiology, the ticks were processed for virus isolation.

Twenty-five nymphs of all stages were killed by chilling $2 \mathrm{~d}$ after receipt and ground up in $2 \mathrm{ml}$ of $0.75 \%$ bovine albumin in borate buffered saline at $p \mathrm{H} 9$ (BABS) with $1,000 \mathrm{U}$ of penicillin and $1 \mathrm{mg}$ of streptomycin $\mathrm{ml}^{-1}$. After centrifugation, the supernatant fluid was inoculated into two litters of eight 1-d-old white mice (TO strain), each mouse receiving $0.02 \mathrm{ml}$ intracerebrally and $0.03 \mathrm{ml}$ subcutaneously. The rest of the tick suspension was stored in sealed glass ampoules at $-60^{\circ} \mathrm{C}$. One litter was lost through the mother's eating the babies. Eleven days after inoculation, two of the mice in the second litter were paralysed and three were ill. A $10 \%$ brain suspension in BABS from two of the ill mice was inoculated intracerebrally into a further four litters of 2-d-old mice. A broth culture of the brain suspension was negative. The isolate in the second passage in suckling mice had an incubation period of $6 \mathrm{~d}$. Third passage mouse brain suspension of the prototype strain (A2070-1) had an intracerebral titre of $7.0 \log$ per $0.02 \mathrm{ml}$ in suckling mice. The agent was pathogenic to adult mice also and the incubation period in 3 to 4-week-old mice inoculated intracerebrally with $10^{-4}$ dilution of third passage suckling mouse brain suspension was $6 \mathrm{~d}$. Third and fourth passage mouse brain suspensions titred $5.9 \mathrm{log}$ to $6.5 \mathrm{log}$ per $0.03 \mathrm{ml}$ intracerebrally in adult mice. The agent has been named Zirqa virus. The virus has been reisolated from the original tick suspension after more than $3 \mathrm{yr}$ storage at $-60^{\circ} \mathrm{C}$ and the identity of the isolate confirmed by complement fixation tests. Additional strains of the virus were also isolated from ticks sent to NAMRU-3, Cairo, by Dr R. E. Williams.

Further tests done at the Microbiological Research Estab- lishment at Porton (D. I. H. S. and E. T. W. B.) showed that the mouse intracerebral $\mathrm{LD}_{50}$ of the agent was reduced by $3.4 \mathrm{log}$ after treatment with an equal volume of ether at $4^{\circ} \mathrm{C}$ for $1 \mathrm{~h}$ and by $\geq 4.6 \mathrm{log}$ after treatment with a final concentration of $0.1 \%$ sodium deoxycholate at $37^{\circ} \mathrm{C}$ for $1 \mathrm{~h}$. An antigen prepared from third passage mouse brain suspension after sucrose-acetone extraction, sonication and trypsin and protamine treatment and tested in haemagglutinin inhibition (HI) tests against antisera to selected arboviruses showed that the agent did not belong to arbovirus serological groups A, B, Bunyamwera, Simbu, California, Kaisodi or Bakau.

A screening complement fixation test done at the Yale Arbovirus Research Unit (J. C.) with immune serum for Zirqa virus and all antigens from non-group $B$ tick-borne viruses to hand (about 40) established the virus as a new agent in the Hughes group of tick-borne arboviruses, closer to Farallon than to the other viruses of the group (Table 1).

Table 1 Relationship between Zirqa Virus and Other Members of the Hughes Group as Determined by Complement Fixation Tests

\begin{tabular}{lccc}
\hline$\quad$ Antigen & Zirqu & Serum & \\
$\quad$ & Farallon & Punta Salinas \\
Zirqa (A2070-1) & $512 / 128^{*}$ & $64 / 64$ & $1: 8$ \\
Farallon & $64 / 512$ & $512 / 512$ & $1: 32$ \\
Hughes & $16 / 16+$ & & $1: 32$ \\
$\begin{array}{l}\text { Soldado } \\
\text { Punta Salinas } \\
\text { (Cal Ar 888) }\end{array}$ & $16 / 16$ & & $1: 8$ traces \\
Normal & & & $1: 128$ \\
& $0 / 0$ & $0 / 0$ & 0 \\
\hline
\end{tabular}

* Reciprocal of serum titre/reciprocal of antigen titre.

All the viruses in the Hughes group, including Zirqa, are associated with marine birds and Ornithodoros spp. The investigation of similar biocenoses elsewhere may reveal the existence of other viruses. There is no known human illness associated with Farallon, Hughes or Soldado viruses. Punta Salinas isolated from Ornithodoros amblus, a species closely related to $O$. muesebecki, has been identified as a member of the Hughes group (H. Johnson, personal communication). Dr Johnson informs us that this virus and another, Huacho virus, belonging to the Kemorovo-Chenuda group, may be likely candidates for the febrile illness associated with tick bites that occurs among guano workers off the coast of Peru. On Zirqa Island, the ticks appeared within a matter of minutes on the nearby ground surface when a person placed a bare foot near cormorants' nests and some dexterity was required to avoid being bitten ${ }^{1}$. There is no clear evidence so far that Zirqa virus was the aetiological agent of the illness among the petroleum industry workers on Zirqa Island, but the isolation of this virus underlines the potential danger to man when he makes effective contact with such silent foci of infection.

We are grateful to the late Dr R. M. Oliver and to Dr J. G. Clothier, Chief Medical Officer of the British Petroleum Company Ltd, for bringing our attention to the tick and for much of the information about the island and the tick.

\section{G. R. VARMA}

Department of Entomology,

London School of Hygiene and Tropical Medicine,

London WC1E 7 HT

\section{E. T. W. BOWEN}

D. I. H. SIMPSON

Microbiological Research Establishment, Porton

Yale Arbovirus Research Unit,

J. Casals

60 College Street, New Haven, Connecticut 06510

Received March 7, 1973.

${ }^{1}$ Hoogstraal, H., Oliver, R. M., and Guirgis, S. S., Ann. ent. Soc. Am., 63, $1762(1970)$

${ }^{2}$ Hoogstraal, H., Proc. ent. Soc. Wash., 71, 368 (1969). 